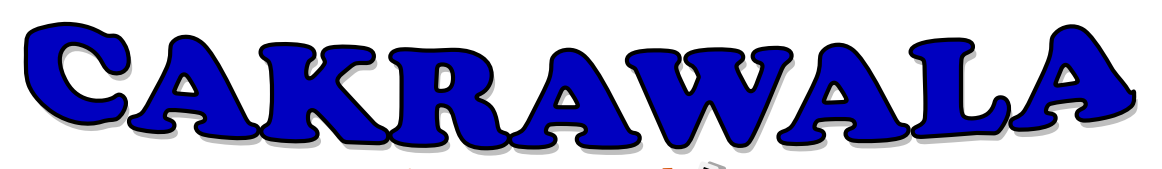

Management Business Journal [CM:-BJ] Volume 1 Nomor 1 Tahun 2018

\title{
PERHITUNGAN PSAK 23 (PENDAPATAN OPERASIONAL, NON OPERASIONAL) DAN PELAPORAN KEUANGAN PERUSAHAAN PADA PT JASA MARGA (PERSERO) TBK
}

\author{
Achmad Fauzi $^{1}$ \\ Universitas $\mathrm{BSI}^{1}$ \\ Correspondence email: achmad_fauzioke@yahoo.com
}

Page | - $102-$

\begin{abstract}
ABSTRAK
PSAK nomor 23 diuraikan dan dijelaskan tentang pengakuan pendapatan yang dapat digunakan bagi perusahaan.

Metode pengumpulan dalam Penelitian ini adalah metode penelitian Kualitatif dengan studi kasus.

Penerapan pengakuan pendapatan Opersional, non Operasional, dan Penerapannya Dengan Laporan Keuangan Perusahaan. PT Jasa Marga menggunakan metode cash basis sebagai dasar pengakuan pendapatan, pendapatan hanya diperhitungkan berdasarkan penerimaan dan pengeluaran kas, dengan penggunaan dasar tunai. PT Jasa Marga menerapkan Standar Pelayanan Minimum (SPM) untuk mendapatkan pendapatan yang bersifat normal dan kegiatan yang dilakukan oleh perusahaan dapat berjalan dengan baik.
\end{abstract}

\section{ABSTRACT}

PSAK number 23 is described and explained about revenue recognition that can be used for companies.

The collection method in this study is a qualitative research method with case studies.

Implementation of operational, non-operational, and application revenue recognition with the Company's financial statements. PT Jasa Marga uses the cash basis method as a basis for revenue recognition, revenue is only calculated based on cash receipts and disbursements, with basic cash usage. PT Jasa Marga implements Minimum Service Standards (SPM) to obtain normal income and activities carried out by the company can run well.

Keyword: Application, Operational Income, Non Operational, Financial Statements 


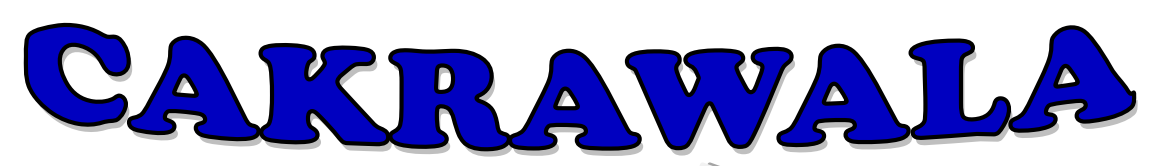

\section{Management Business Journal [CM]-BJ] Volume 1 Nomor 1 Tahun 2018}

\section{PENDAHULUAN}

Hasil akhir dari suatu proses akuntansi keuangan adalah dihasilkannya informasi keuangan mengenai posisi keuangan dan hasil operasi suatu entitas akuntansi dalam bentuk seperangkat laporan keuangan (financial statement), yang ditujukan untuk memenuhi kebutuhan umum (general purpose). Keseluruhan proses akuntansi ini diatur oleh standar yang dituangkan dalam prinsip-prinsip akuntansi yang lazim atau diterima umum. yang menentukan informasi yang dicantumkan dalam laporan keuangan. Prinsip akuntansi yang lazim ini mencerminkan sasaran dan segi keutamaan dasar akuntansi keuangan khusus di Indonesia standar ini adalah Standar Akuntansi Keuangan (PSAK).

Prinsip akuntansi adalah petunjuk umum atau pedoman dasar dalam menyusun laporan keuangan. Tanpa adanya pedoman ini mungkin masing-masing perusahaan atau masing-masing akuntan akan menyusun keuangannya dengan caranya sendiri, sehingga laporan keuangan tersebut tidak dapat dianalisis ataupun dibandingkan dengan yang lainnya.Prinsip akuntansi disusun berdasarkan beberapa asumsi atau anggapan yang disebut sebagai konsep dasar. Asumsi-asumsi atau anggapan-anggapan ini tidak dapat diuji kebenarannya secara otomatis. Dengan perkataan lain asumsi ini dapat diterima tanpa suatu pembuktian.

Setiap perusahaan menginginkan tingkat pertumbuhan yang baik. Pertumbuhan tersebut tercermin dengan pencapaian tingkat laba yang diperoleh oleh perusahaan. Setiap elemen yang ada di dalam perusahaan akan berusaha untuk mendapatkan laba yang telah ditetapkan oleh manajemen, bahkan melebihi target dari manajemen tersebut. Pertumbuhan perusahaan dapat dilihat dari laporan keuangan yang sudah disiapkan oleh perusahaan, salah satunya adalah laporan laba rugi yang didalamnya terdapat unsur pendapatan dan biaya dalam suatu periode tertentu. Pendapatan tentu mempengaruhi laba rugi yang tersaji di laporan laba rugi tersebut.

Menurut PSAK 23, pendapatan adalah arus kas masuk bruto dari manfaat ekonomik yang timbul dari aktivitas normal entitas selama suatu periode, jika arus masuk tersebut mengakibatkan kenaikan ekuitas yang tidak berasal dari kontribusi penanaman modal.Dengan pengertian diatas, maka perusahaan tidak boleh mencatat Pajak yang dipotong dari pihak lain sebagai pendapatan walaupun pajak merupakan kas masuk ke perusahaan. Disisi lain perusahaan yang bergerak sebagai agen (bukan orang yang 


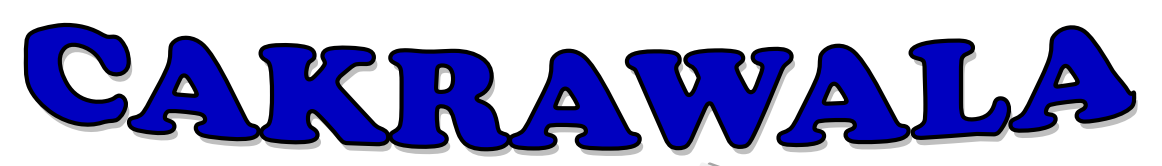

\section{Management Business Journal [C:M:B. J] Volume 1 Nomor 1 Tahun 2018}

sebenarnya) dari sebuah transaksi tidak boleh mengakui kas yang masuk sebagai pendapatannya, namun hanya mengakui komisi sebagai pendapatannya.Secara umum, perusahaan dapat memperoleh pendapatan (arus kas masuk) melalui 3 cara, yaitu;

1. Penjualan barang (termasuk barang dagangan dan aset spesifik)

2. Penjualan jasa

3. Bunga dan royalti (passive income)

Menurut Suwardjono PSAK ( Pernyataan Standar Akuntansi ), (2008:211), mengatakan bahwa "Standar akuntansi adalah konsep, prinsip, metode, teknik, dan lainnya yang sengaja dipilih atas dasar kerangka konseptual oleh badan penyusun standar (atau yang berwenang) untuk diberlakukan dalam bentuk dokumen resmi guna mencapai tujuan pelaporan keuangan negara tersebut.

Ada empat alasan mengapa standar akuntansi dibuat menurut Belkoui (2006:161) yaitu :

1. Standar memberikan informasi mengenai posisi keuangan, kinerja, dan penyelenggaraan sebuah perusahaan kepada para pengguna informasi akuntansi, informasi ini dianggap jelas, konsisten, andal, dan dapat diperbandingkan.

2. Standar memberikan pedoman dan aturan tindakan bagi para akuntan publik yang memungkinkan mereka untuk menerapkan kehati-hatian dan mengaudit laporanlaporan perusahaan dan membuktikan validitas dalam laporan-laporan tersebut.

3. Standar memberikan database kepada pemerintah mengenai berbagai variabel yang dianggap sangat penting dalam pelaksanaan perpajakan, regulasi perusahaan, perencanaan dan regulasi ekonomi, serta peningkatan efisiensi dan sasaran-sasaran sosial lainnya.

4. Standar menumbuhkan minat dalam prinsip-prinsip dan teori-teori bagi mereka yang memiliki perhatian dalam disiplin ilmu akuntansi.

Pengakuan Pendapatan Dalam Pernyataan Standar Akuntansi Keuangan (PSAK) Nomor 23 paragraf ke 23 (Revisi 2012) menyatakan bahwa pendapatan diakui bila besar kemungkinan manfaat ekonomi masa depan akan mengalir ke perusahaan. Pernyataan Standar Akuntansi Keuangan No. 23 paragraf ke 24 (Revisi 2012) menyatakan bahwa penjualan jasa dapat diakui dengan persentase penyelesaian bila memenuhi kondisi berikut:

1. Jumlah pendapatan dapat dikur dengan andal. 


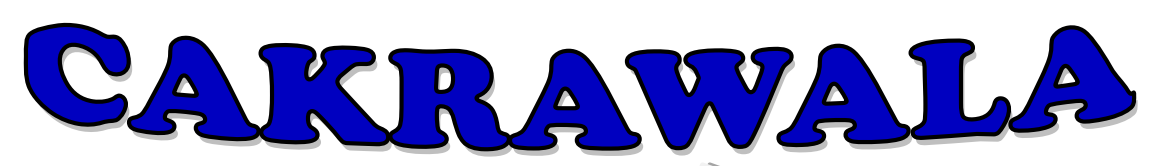

\section{Management Business Journal [C:M:BJ] Volume 1 Nomor 1 Tahun 2018}

2. Kemungkinan besar manfaat ekonomi sehubungan dengan transaksi tersebut akan mengalir ke entitas.

3. Tingkat penyelesaian dari suatu transaksi pada akhir periode pelaporan dapat diukur secara andal.

4. Biaya yang timbul untuk transaksi dan biaya untuk menyelesaikan transaksi tersebut dapat diukur secara andal.

Menurut PSAK No.23 paragraf ke 23 (Revisi 2012) nilai wajar adalah jumlah suatu asset dipertukarkan atau liablitas diselesaikan antara pihak-pihak yang berkeinginan dan memilikipengetahuan dalam suatu transaksi yang wajar.

Pendaatan menurut Menurut Ikatan Akuntansi Indonesia (2010:23), menyatakan bahwa "Pendapatan adalah arus kas masuk bruto dari manfaat ekonomi yang timbul dari aktivitas normal perusahaan selama satu periode bila arus masuk tersebut mengakibatkan kenaikan ekuitas, yang tidak berasal dari kontribusi penanaman modal.Santoso (2010:26) , Pendapatan merupakan pemasukan atau peningkatan aktiva suatu perusahaan atau penyelesaian kewajiban perusahaan atau campuran keduanya selama satu periode tertentu akibat penyerahan atau pembuatan suatu produk, pelayanan jasa, atau kegiatan lain yang merupakan kegiatan utama perusahaan yang berkesinambungan.Samryn (2014:43) pendapatan adalah "Aliran masuk aktiva atau pengurangan utang yang diperoleh dari hasil penyerahan barang atau jasa kepada para pelanggan.

Pengertian pendapatan sering disama artikan dengan istilah penghasilan, tetapi sebenarnya berbeda. Perbedaan dijelaskan dalam definisi sebagai berikut:

"Penghasilan didefinisikan sebagai peningkatan manfaat ekonomi selama periode akuntansi dalam bentuk arus masuk atau peningkatan aset atau penurunan liabilitas yang mengakibatkan kenaikan ekuitas, yang tidak berasal dari kontribusi penanaman modal. Penghasilan meliputi pendapatan maupun keuntungan".(IAI:2010:23)

Jenis-jenis pendapatan dapat dibedakan menjadi 2 bagian Menurut Kusnadi (2000:19) yaitu:

a. Pendapatan operasional

Pendapatan Operasional adalah pendapatan yang timbul dari penjualan barang dagangan, produk atau jasa dalam periode tertentu dalam rangka kegiatan utama atau yang menjadi tujuan umum perusahaan yang berhubungan langsung dengan usaha 
(operasi) pokok perusahaan yang bersangkutan.Pendapatan ini sifatnya normal sesuai dengan tujuan dan usaha perusahaan dan terjadinya berulang-ulang selama perusahaan melangsungkan kegiatannya.

b. Pendapatan Non Operasional

Pendapatan yang diperoleh perusahaan dalam periode tertentu, akan tetapi bukan diperoleh dari kegiatan operasional perusahaan.

Theodorus M.Tuanakotta $(2000 ; 153)$ menyatakan bahwa pada dasarnya ada dua pendekatan terhadap konsep pendapatan (revenue)yaitu :

1. Pendekatan yang memusatkan perhatian kepada arus masuk (inflow) daripada assets yang ditimbulkan oleh kegiatan operasional perusahaan.

2. Memusatkan perhatian kepada pencapaian barang dan jasa oleh perusahaan dan transfer dari barang dan jasa kepada konsumen atau produsen lain.

Disamping itu terdapat dua konsep yang sangat erat berhubungan dengan masalah proses pendapatan yaitu :

1. Proses pembentukan pendapatan (Earnings Process)

Proses pembentukan pendapatan adalah suatu konsep tentang terjadinya pendapatan. Konsep ini berdasarkan pada asumsi bahwa semua kegiatan operasi yang diperlukan dalam rangka mencapai hasil, yang meliputi semua tahap kegiatan produksi, pemasaran, maupun pengumpulan piutang, memberikan kontribusi terhadap hasil akhir pendapatan berdasarkan perbandingan biaya yang terjadi sebelum perusahaan tersebut melakukan kegiatan produksi.

2. Proses realisasi pendapatan (realization process)

Proses realisasi pendapatan adalah proses pendapatan yang terhimpun atau terbentuk sesudah produk selesai dikerjakan dan terjual atas dikontrak penjualan. Jadi, pendapatan dimulai dengan tahap akhir kegiatan produksi, yaitu pada saat barang atau jasa dikirimkan atau diserahkan kepada pelanggan. Jika, kontrak penjualan mendahului produksi barang atau jasa maka pendapatan belum dapat dikatakan terjadi, karena belum menjadi terjadi proses penghimpunan pendapatan.

Pengakuan Pendapatan, berarti proses pembentukan suatu pos yang memenuhi definisi unsur kriteria pengakuan yang sesuai dengan standar akuntansi dalam laporan neraca dan laba rugi, yaitu harahap (2011:96) menyatakan: 
1. Ada kemungkinan manfaat ekonomi yang berkaitan dengan pos tersebut akan mengalir dari atau ke dalam perusahaan.

2. Pos tersebut mempunyai nilai atau biaya yang dapat diukur dengan andal.

Pendapatan dan keuntungan diakui apabila sebagai berikut:

1. Pendapatan dan keuntungan telah direalisasi

2. Pendapatan dihasilkan

Kedua ktiteria itu diatas biasanya dipenuhi pada titik penjualan (point of sale), yang sering terjadi ketika barang diantara atau ketika pelayanan diberikan kepada pelanggan.

Belkoui (2013:569) menyatakan bahwa ada dua metode pengakuan pendapatan dalam periode akuntansi, yaitu:

\section{Accrual Basis}

Teknik accrual basis memiliki fitur pencatatan dimana transaksi sudah dapat dicatat karena transaksi tersebut memiliki implikasiuang masuk atau keluar di masa depan. Transaksi dicatat pada saat terjadinya walupun uang belum benar-benar diterima atau dikeluarkan.Dengan kata lain basis akrual digunakan untuk pengukuran asset, kewajiban dan ekuitas dana. Jadi, accrual basis adalah basis akuntansi yang mengakui pengaruh transaksi dan peristiwa lainnya pada saat transaksi dan peristiwa itu terjadi tanpa memperhatikan saat kas atau setara kas diterima atau dibayar.

\section{Tabel 1}

Jurnal Pendapatan dan Kas

Pada saat diakui pendapatan yang ditandai

dengan perpindahan pemilikan dari penjual ke pembeli

\begin{tabular}{|c|c|c|}
\hline Piutang & $X x x$ & Kas \\
\hline Penjualan & $X x x$ & Piutang \\
\hline
\end{tabular}

Sumber : Kieso, Weygandt dan Warfield , (2011:517)

\section{Cash Basis}

Dalam metode cash basis, pendapatan diakui ketika kas diterima sedangkan beban diakui saat kas dibayarkan, artinya perusahaan mencatat beban didalam transaksi jurnal entry ketika kas dikeluarkan atau dibayarkan dan pendapat dicatat ketika kas masuk atau diterima.

Tabel 2

Jurnal Pencatatan pada saat pendapatan dana kas diterima 


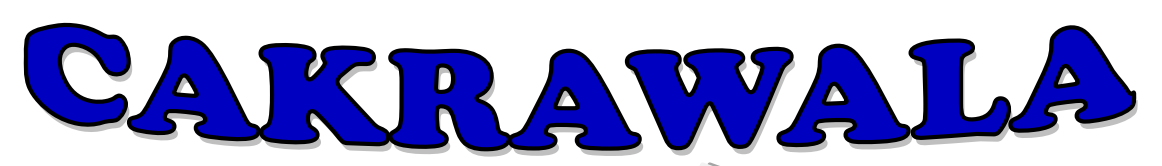

Management Business Journal [CM:-BJ] Volume 1 Nomor 1 Tahun 2018

\begin{tabular}{lc}
\hline Kas & $\mathrm{Xxx}$ \\
& Penjualan \\
& $\mathrm{Xxx}$ \\
\hline
\end{tabular}

Sumber : Kieso, Weygandt dan Warfield , (2011:517)

Hasil penelitian sebelumnya yaitu Desi Eliza Purba, dalam penelitiannya Penerapan

PSAK 23 Tentang Akuntansi Pendapatan Studi Pada PT Angkasa Pura II Bandar Udara Raja Haji Fisabilillah (RHF).Tujuan dari penelitian ini adalah untuk mengetahui apakah pengakuan, pengukuran dan pengungkapan pendapatan pada Bandar Udara Raja Haji Fisabilillah (RHF) Tanjungpinang telah sesuai secara keseluruhan dengan PSAK No. 23. Selain pengakuan, pengukuran menjadi masalah lain yang cukup rumit dalam penerapan akuntansi pendapatan. Hal ini disebabkan adanya pertanyaan tentang apa yang menjadi dasar pengukuran itu dan berapa besar pendapatan yang akan diterima perusahaan. Pada PT (Persero) Angkasa Pura II Bandar Udara Raja Haji Fisabilillah Tanjungpinang, penghitungan pendapatan dihitung dengan mengalikan jasa yang diterima dengan tarif yang berlaku. Tarif tersebut merupakan ketetapan hitungan yang didasarkan pada usulan dari cabang yaitu PT (Persero) Angkasa Pura II Bandar Udara Raja Haji Fisabilillah Tanjungpinang. Untuk pendapatan tertentu, tarif yang berlaku di PT (Persero) Angkasa Pura II Bandar Udara Raja Haji Fisabilillah Tanjungpinang tidak sama dengan Bandar udara yang lain. Hal ini disebabkan karena usulan tarif dari cabang merupakan hasil pengamatan atau survei yang berlaku di sekitar kawasan kerja kantor cabang, dalam hal ini adalah tarif ratarata di kota Tanjungpinang.

Rina Dwirinawati, dalam penelitiannya Pengakuan Dan Pengukuran Pendapatan menurut PSAK No. 23 Pada Perusahaan Biro Jasa Perjalanan. Tujuan dari penelitian ini adalah Tujuan dilakukan penelitian ini untuk mengetahui apakah metode yang diterapkan oleh perusahaan dalam mengakui dan mengukur pendapatannya telah sesuai dengan PSAK Nomor23. Aspek-aspek masalah yang diteliti oleh penulis yaitu mengenai pencatatan transaksi, pengakuan pendapatandan besarnya pendapatan. Hasil penelitian pada PT. Megananda Trans, metode yang diterapkan untuk mengakui pendapatannya adalah metode dasar kas dimana pendapatan diakui pada saat penerimaan pembayaran. Seharusnya pengakuan pendapatan PT. Megananda Trans menggunakan metode dasar akrual yang mana pendapatan diakui pada saat terjadinya transaksi, sebagaimana telah 


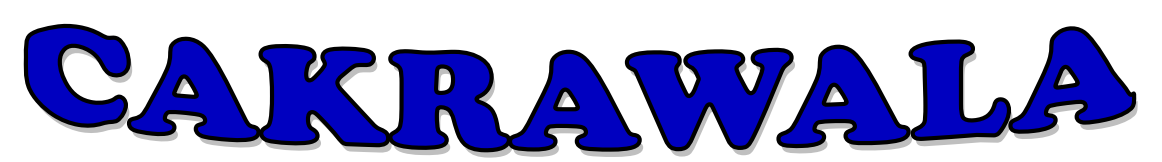

\section{Management Business Journal [CM:-BJ] Volume 1 Nomor 1 Tahun 2018}

ditetapkan dalam Standar Akuntansi Keuangan sehingga laporan keuangan yang disajikan dapat diandalkan. Untuk pengukuran pendapatan PT.Megananda Trans telah menetapkan Pernyataan Standar Akuntansi Keuangan atau PSAK Nomor 23 terlihat daripengakuan pendapatan yang diukur dengan nilai wajar imbalan yang diterima atau yang dapat diterima oleh perusahaan. Pengakuan pendapatan yang berasaldari aktivitas usaha pada PT. Megananda Trans menggunakan metode cash basis yaitu yang manapendapatan diakui pada saat terjadinya penerimaan pembayaran. Pengakuan pendapatan yangditerapkan pada PT. Megananda Trans belum sesuai dengan ketentuan yang diatur dalam PSAK No. 23, Pengukuran pendapatan yang diterapkan PT. Megananda Trans menggunakan nilai wajar sebagaiukuran dalam mengukur pendapatan yang diakui. Pengukuran pendapatan yang diterapkan pada PT.Megananda Trans telah sesuai dengan ketentuan menurut PSAK No. 23 yang menyatakan bahwapendapatan harus diukur dengan nilai wajar imbalan yang diterima atau yang dapat diterima. Berdasarkan teori dan penelitian terdahulu maka kerangka berpikir dalam penelitian ini, aalah:

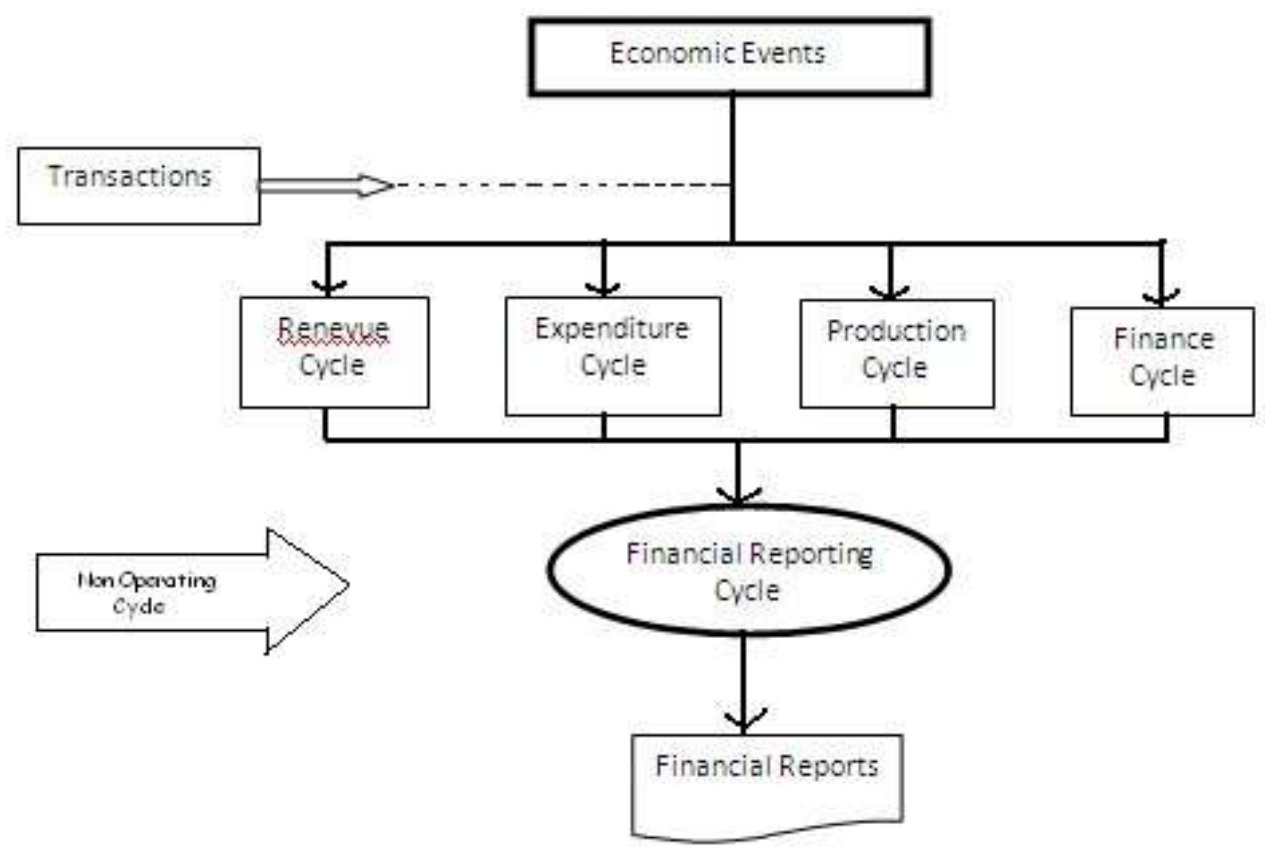

Gambar 1

Kerangka Berpikir 


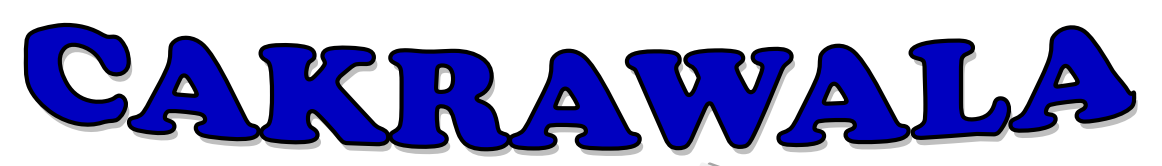

\section{Management Business Journal [CM:-BJ] Volume 1 Nomor 1 Tahun 2018}

\section{METODE PENELITIAN}

Berdasarkan fokus dan tujuan penelitian, maka penelitian ini merupakan kajian yang mendalam guna memperoleh data yang lengkap dan terperinci.Untuk itu penelitian ini menggunakan pendekatan deskriptif kualitatif. Bafadal , (2015:40 ) Adapun teknik analisis data yang akan dilakukan peneliti yaitu :

1. Reduksi data. Data yang diperoleh di lapangan sebelum dilakukan laporan lengkap dan terperinci disortir dulu, yaitu yang memenuhi fokus penelitian. Dalam mereduksi data, semua data lapangan ditulis sekaligus dianalisis, direduksi, dirangkum, dipilih hal-hal yang pokok, difokuskan pada hal-hal yang penting, dicari tema da polanya, sehingga disusun secara sistematis dan lebih mudah dikendalikan.

2. Penyajian dataDalam penelitian ini peneliti akan menyajikan data dalam bentuk laporan berupa uraian yang lengkap dan terperinci. Ini dilakukan peneliti agar data yang diperoleh dapat dikuasai dengan dipilah secara fisik dan dipilah kemudian dibuat dalam kertas dan bagan.

3. Menarik kesimpulan. Dalam penelitian ini, setelah dilakukan verifikasi maka akan ditarik kesimpulan yang merupakan hasil dari penelitian ini. Yaitu dengan cara mencari makna fokus penelitian.

Peneliti melakukan verifikasi dan menarik kesimpulan guna mencari makna yang terkandung di dalamnya. Pada awalnya kesimpulan yang dibuat bersifat tentatif, kabur, dan penuh keraguan, tetapi dengan bertambahnya data dan pembuatan kesimpulan demi kesimpulan akan ditemukan data yang dibutuhkan. Berikut adalah "model interaktif" yang digambarkan oleh Miles dan Huberman (2014)

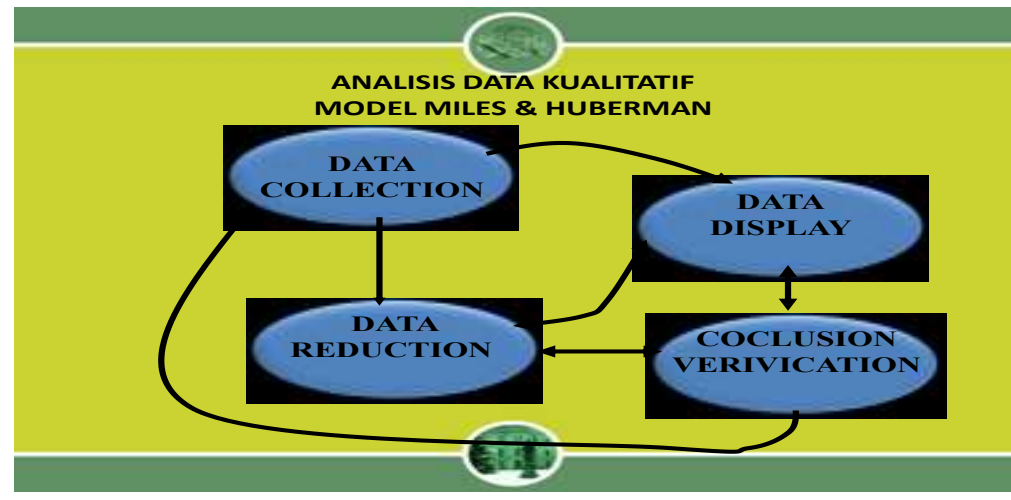

Gambar 2

Alur analisa data 


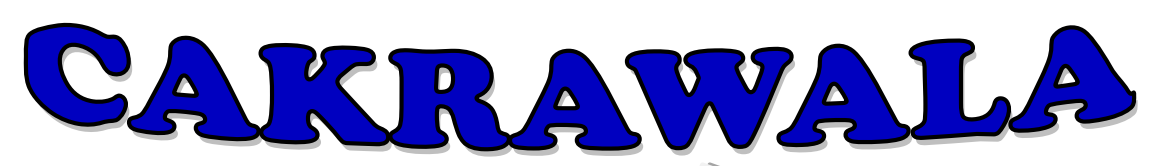

\section{Management Business Journal [CM]-BJ] Volume 1 Nomor 1 Tahun 2018}

Patton (2006) dalam wawancara harus meliputi beberapa aspek sebagai berikut: 1) pertanyaan tentang tingkah laku atau pengalaman. Pertanyaan ini untuk memperoleh pengalaman, tingkah laku, tindakan, dan kegiatan; 2) pertanyaan tentang opini atau nilai. Pertanyaan ini digunakan untuk pemahaman kognitif dan proses penafisiran orang; 3 ) pertanyaan tentang perasaan. Pertanyaan ini digunakan untuk pemahaman tanggapan emosional orang terhadap pengalaman dan pikiran; 4) pertanyaantentang pengetahuan, digunakan untuk menemukan informasi factual apa yang dimiliki responden; 5) pertanyaan tentang indera, pertanyaan untuk memperoleh tentang apa yang dilihat, didengar, diraba dan dibau; 6) pertanyaan tentang latar belakang atau demografis digunakan untuk identifikasi responden.

Pada dasarnya penelitian kualitatif dapat digunakan untuk ketiga maksud tersebut . Lexy J. Moleong (2013 ) Ditinjau dari segi sifat-sifat data maka termasuk dalam penelitian Kualitatif yaitu penelitian yang bermaksud untuk memahami fenomena tentang apa yang dialami oleh subjek penelitian misalnya perilaku, persepsi, motivasi, tindakan dan lain-lain secara holistik, dan dengan cara deskripsi dalam bentuk kata-kata dan bahasa, pada suatu konteks khusus yang alamiah dan dengan memanfaatkan berbagai metode alamiah.

Studi kasus juga berusaha mendeskripsikan suatu latar, objek atau suatu peristiwa tertentu secara mendalam. Pendapat ini didukung oleh Yin, ( $2002: 25$ ) yang menyatakan bahwa studi kasus merupakan strategi yang dipilih untuk menjawab pertanyaan how dan why, jika fokus penelitian berusaha menela'ah fenomena kontemporer (masa kini) dalam kehidupan nyata. Menurut Nasution, ( 2005 : 23 ) Salah satu keunikan dalam penelitian kualitatif adalah bahwa peneliti itu sendiri sebagai instrumen utama, sedangkan instrumen non insani bersifat sebagai data pelengkap. Kehadiran peneliti merupakan tolok ukur keberhasilan atau pemahaman terhadap beberapa kasus.Peneliti bertindak sebagai instrumen utama dalam pengumpulan data atau instrumen kunci.

Penelitian dilakukan dalam latar (setting) yang alamiah (naturalistic) bukan hasil perlakuan (treatment) atau manipulasi variabel yang dilibatkan.Observasi digunakan untuk menghasilkan penjelasan yang sangat mendalam mengenai organisasi dan peristiwa, untuk mendapatkan informasi yang tidak dapat diperoleh dengan cara lain, dan untuk melakukan penelitian di saat metode-metode lain tidak memadai. 


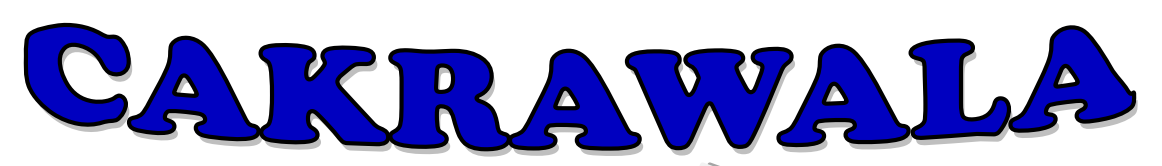

\section{Management Business Journal [CM:-BJ] Volume 1 Nomor 1 Tahun 2018}

\section{Tahap Penelitian Kualitatif}

tahapan yang harus dilakukan dalam penelitian kualitatif yang harus dilakukan tahap demi tahap. Secara umum, tahap penelitian meliputi: 1. membuat rancangan penelitian; 2. membuat instrumen penelitian; 3. mengumpulkan data; 4. mengolah dan menganalisis data; 5. membuat laporan.

\section{Ruang Lingkup Studi}

Lingkup kegiatan dari kajian penelitian meliputi:

a) Lingkup Wilayah Studi. Wilayah kegiatan penelitian adalah PT Jasa Marga , Persero

b) Lingkup Obyek Studi. Lingkup Objek studi adalahPendapatan Operasional, nonOperasional dan Laporan Keuangan Perusahaan

c) Lingkup Kegiatan Studi.Lingkup kegiatan Penelitian Pendapatan Operasional , NonOperasional dan Laporan Keuangan Perusahaan yang terdiri dari ;

(1) Proses persiapan

Tahap persiapan pekerjaan, menyusun kelengkapan data ( berkas ) mobilisasi sumber daya pekerjaan (termasuk informan terkait), rencana kegiatan, jadwal pelaksanaan dan lain sebagainya, yang dikonsultasikan.

(2) Pengumpulan Data

Pengumpulan data dilakukan dengan mengumpulkan data primer, data sekunder, kunjungan lapangan untuk obsevarsi wilayah kajian serta studi-studi yang mendukung kajian studi ini.

Analisis data dalam penelitian ini, yaitu :

Tabel 3

Data PenelitianPendapatan Opersional , Non Operasional

\begin{tabular}{|c|c|c|c|c|c|}
\hline \multicolumn{6}{|c|}{ LABA RUGI FORMAT PROGNOSA } \\
\hline \multicolumn{6}{|c|}{ PERIODE DESEMBER } \\
\hline \multicolumn{6}{|c|}{ CABANG CAWANG TOMANG CENGKARENG } \\
\hline Uraian & Balance & Balance & $\begin{array}{l}\text { Balance } \\
\text { Budget }\end{array}$ & Varian & $\%$ \\
\hline & Tahun Lalu & Tahun ini & Tahun ini & & \\
\hline \multicolumn{6}{|l|}{ OPERASI YANG } \\
\hline \multicolumn{6}{|l|}{ DILANJUTKAN } \\
\hline \multirow[t]{2}{*}{ Pendapatan Tol } & 1.062.247.71 & 1.109 .956 .63 & 1.087.509.06 & 22.447 .565 & \\
\hline & $9.065,00$ & $2.081,00$ & $6.565,00$ & 516,00 & 2,06 \\
\hline \multirow[t]{2}{*}{ Pendapatan Konstruksi } & 47.324.795.4 & - & - & - & $\mathrm{n} / \mathrm{m}$ \\
\hline & 07,55 & & & & \\
\hline Pendapatan Usaha Lain & 27.079 .092 .3 & 32.706 .793 .1 & 26.247 .000 .0 & 6.459 .793 .1 & \\
\hline
\end{tabular}




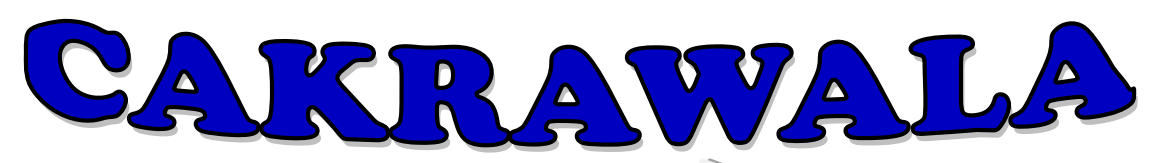

Management Business Journal [CM]-BJ] Volume 1 Nomor 1 Tahun 2018

\begin{tabular}{|c|c|c|c|c|c|}
\hline & 30,57 & 58,16 & 00,00 & 58,16 & 24,6 \\
\hline & & & & & 1 \\
\hline \multirow[t]{2}{*}{ Jumlah Pendapatan Usaha } & 1.136 .651 .60 & 1.142 .663 .42 & 1.113.756.06 & 28.907 .358 & \\
\hline & $6.803,12$ & $5.239,16$ & $6.565,00$ & 674,16 & 2,60 \\
\hline \multicolumn{6}{|l|}{ Beban Usaha } \\
\hline \multirow[t]{2}{*}{ Beban SDM } & 122.413 .587 & 139.834 .826$. & 146.743 .757 & 6.908.930.7 & \\
\hline & 237,00 & 829,00 & 615,41 & 86,41 & 4,71 \\
\hline \multirow[t]{2}{*}{ Pengumpulan Tol } & 23.183.537.2 & 29.093.638.6 & 27.135 .637 .4 & 1.958.001.2 & \\
\hline & 52,51 & 31,72 & 25,00 & 06,72 & 7,22 \\
\hline \multirow[t]{2}{*}{ Pelayanan Jalan Tol } & 24.421 .671 .4 & 30.573 .190 .2 & 30.310 .027 .2 & 263.163 .05 & \\
\hline & 78,62 & 83,05 & 30,50 & 2,55 & 0,87 \\
\hline \multicolumn{6}{|l|}{ Pemeliharaan Jalan Tol } \\
\hline & 31.332 .469 .8 & 37.289 .108 .7 & 15.571 .700 .8 & 21.717.407. & 139, \\
\hline & 84,67 & 14,49 & 34,02 & 880,47 & 47 \\
\hline Beban Pajak Bumi dan & & & & $100.000,00$ & - \\
\hline \multirow[t]{2}{*}{ Bangunan } & 32.707 .252 .4 & 48.873 .288 .5 & 48.873 .388 .5 & & \\
\hline & 58,00 & 13,00 & 13,00 & & \\
\hline \multicolumn{6}{|l|}{ Beban Penyusutan dan } \\
\hline \multirow[t]{2}{*}{ Amortisasi } & 59.955 .470 .8 & 74.321 .544 .5 & 74.018 .691 .2 & 302.853 .20 & 0,41 \\
\hline & 53,87 & 00,75 & 93,44 & 7,31 & \\
\hline Kerjasama Operasi & - & - & - & - & $\mathrm{n} / \mathrm{m}$ \\
\hline \multirow[t]{3}{*}{ Beban Konstruksi } & & - & - & - & $\mathrm{n} / \mathrm{m}$ \\
\hline & 47.324.795.4 & & & & \\
\hline & 07,55 & & & & \\
\hline \multicolumn{6}{|l|}{ Umum dan Administrasi } \\
\hline & 11.689.283.8 & 12.599.611.0 & 10.310.471.0 & 2.289 .140 .0 & 22,2 \\
\hline & 47,73 & 27,53 & 10,00 & 17,53 & 0 \\
\hline Penghasilan Bunga & & & - & & $\mathrm{n} / \mathrm{m}$ \\
\hline & 122.772.517, & 244.888.205, & & 244.888 .20 & \\
\hline & 67 & 99 & & 5,99 & \\
\hline Penghasilan Lain Lain & & & - & & $\mathrm{n} / \mathrm{m}$ \\
\hline & 924.505.526, & 1.528.026.18 & & 1.528.026.1 & \\
\hline & 00 & 1,51 & & 81,51 & \\
\hline Beban Lain-Lain & & $57.983,97$ & $4.459 .779,00$ & & \\
\hline & 473.766.404, & & & $4.517 .762,9$ & 101, \\
\hline & 49 & & & 7 & 30 \\
\hline \multirow[t]{2}{*}{ Jumlah Beban Usaha } & 352.454 .556$. & & & & \\
\hline & 780,77 & $\begin{array}{r}370.812 .236 \\
128,07\end{array}$ & $\begin{array}{r}352.968 .133 \\
700,37\end{array}$ & $\begin{array}{r}17.844 .102 \\
427,70\end{array}$ & 5,06 \\
\hline \multicolumn{6}{|l|}{ Laba Usaha } \\
\hline & $\begin{array}{r}784.197 .050 \\
022,35\end{array}$ & $\begin{array}{r}771.851 .189 \\
111,09\end{array}$ & $\begin{array}{r}760.787 .932 \\
864,63\end{array}$ & $\begin{array}{r}11.063 .256 \\
246,46\end{array}$ & 1,45 \\
\hline Beban Bunga & & & - & & $\mathrm{n} / \mathrm{m}$ \\
\hline & 894.724.244, & $65.121 .993,0$ & & 65.121.993, & \\
\hline & 76 & 0 & & 00 & \\
\hline \multicolumn{6}{|l|}{ Asosiasi } \\
\hline Jumlah Pendapatan(Beban) & & & - & & $\mathrm{n} / \mathrm{m}$ \\
\hline Lain-Lain Bersih & $\begin{array}{r}894.724 .244 \\
76\end{array}$ & $\begin{array}{r}65.121 .993,0 \\
0\end{array}$ & & $\begin{array}{r}65.121 .993 \\
00\end{array}$ & \\
\hline
\end{tabular}




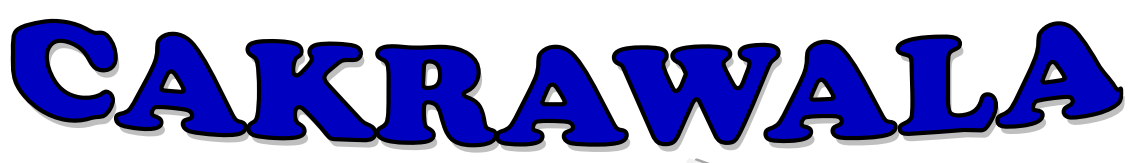

Management Business Journal [CM:-BJ] Volume 1 Nomor 1 Tahun 2018

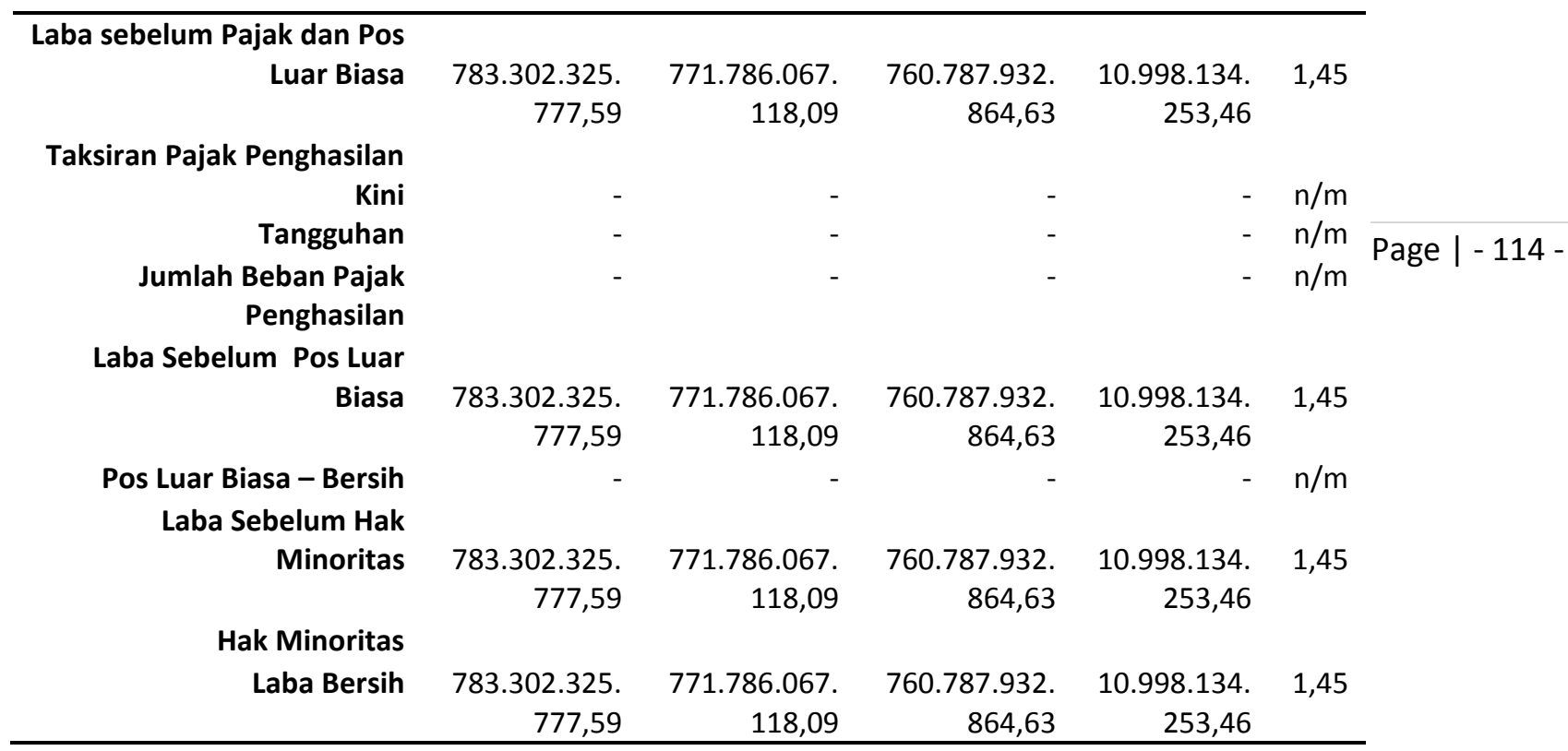

\section{HASIL PENELITIAN}

Hasil pendapatan yang diterima oleh PT Jasa Marga (Persero) Tbk Cawang Tomang Cengkareng yaitu pendapatan operasional dan non operasional berupa pendapatan tol dan lainnya.PT Jasa Marga (Persero) Tbk Cabang Cawang Tomang Cengkareng mengakui pendapatan nya pada saat semua transaksi diterima langsung. Perusahaan menggunakan metode cash basis sebagai dasar pengakuan pendapatan dimana pendapatan diakui atas dasar kejadian penting dimana pendapatan hanya diperhitungkan berdasarkan penerimaan dan pengeluaran kas, dengan penggunaan dasar tunai atau cash basis pendapatan dari penjualan barang atau jasa hanya dapat diperhitungkan pada saat tagihan langganan diterima.Peneliti mendapatkan hasil dari riset yang dilakukan di perusahaan, bahwa PT Jasa Marga (Persero) Tbk Cabang Cawang Tomang Cengkareng telah memenuhi standar sesuai dengan PSAK No.23 Tahun 2010, dan dapat dikatakan perusahaan telah mengakui pendapatan sebagiamana semestinya. Berikut ini adalah salah satu contoh rekapitulasi pendapatan operasional dan non operasional PT Jasa Marga Cabang Cawang Tomang Cengkareng: 
TABEL 4

REKAPITULASI PENDAPATAN OPERASIONAL DAN NON OPERASIONAL BAGIAN KEUANGAN CABANG CAWANG TOMANG CENGKARENG

\begin{tabular}{lllll}
\hline No & \multicolumn{1}{c}{ Bulan } & \multicolumn{1}{c}{ Operasional } & \multicolumn{1}{c}{ Non Operasional } & \multicolumn{1}{c}{ TOTAL } \\
\hline $\mathbf{1}$ & JANUARI & 85.116 .550 .115 & 135.464 .800 & 85.252 .014 .915 \\
$\mathbf{2}$ & FEBRUARI & 166.535 .062 .435 & 356.368 .443 & 166.891 .430 .878 \\
$\mathbf{3}$ & MARET & 252.619 .109 .590 & 678.549 .787 & 253.297 .659 .377 \\
$\mathbf{4}$ & APRIL & 337.820 .542 .425 & 6.410 .729 .815 & 344.231 .272 .240 \\
$\mathbf{5}$ & MEI & 425.745 .300 .270 & 6.700 .786 .259 & 432.446 .086 .529 \\
$\mathbf{6}$ & JUNI & 514.700 .833 .448 & 12.591 .427 .875 & 527.292 .261 .323 \\
$\mathbf{7}$ & JULI & 601.259 .436 .688 & 12.791 .081 .963 & 614.050 .518 .651 \\
$\mathbf{8}$ & AGUSTUS & 682.129 .686 .146 & 12.848 .534 .075 & 694.978 .220 .221 \\
$\mathbf{9}$ & SEPTEMBER & 778.878 .950 .036 & 19.906 .412 .732 & 798.785 .362 .768 \\
$\mathbf{1 0}$ & OKTOBER & 870.370 .495 .915 & 19.975 .719 .912 & 890.346 .215 .827 \\
$\mathbf{1 1}$ & NOVEMBER & 972.622 .218 .484 & 20.391 .258 .664 & 993.013 .477 .148 \\
$\mathbf{1 2}$ & DESEMBER & 1.062 .247 .719 .065 & 27.378 .154 .121 & 1.089 .625 .873 .186 \\
\hline
\end{tabular}

\section{PEMBAHASAN}

Proses pencatatan pengakuan pendapatan PT Jasa Marga (Persero) Tbk Cabang Cawang Tomang Cengkareng dimuai dari hasil pendapatan tol ruas Cawang sampai dengan Pluit yang dikumpulkan pada bagian pengumpulan toldan disetorkan ke bank, bukti setoran bank dan bukti transfer diterima langsung dari bank, transfer otomatis dilakukan setiap hari langsung dibukukan oleh bank, lalu di bagian manajemen pengumpulan tol rekonsiliasi data setoran bank dibuat invoice voucherpenerimaan saat itulah pendapatan baru diakui, dan diinput data ke laporan laba rugi komprehensif lalu diproses menjadi laporan neraca mutasi bulanan.

Untuk contoh dari penerapan cash basis yang dilakukan oleh kantor pusat yaitu sebagai berikut, selama bulan januari 2014 perusahaan mendapatkan total penghasilan dari pendapatan operasional dan non operasional sebesar 94.816 .404 .703 dan dikurangi pajak penghasilan yaitu $24 \%$ pertahun.

Dengan demikian jurnal yang dibuat sehubungan dengan total pendapatan operasional dan non operasional adalah sebagai berikut :

Perhitungan pendapatan bersih yang diterima oleh PT Jasa Marga (Persero) Tbk Cabang Cawang Tomang Cengkareng :

- Pajak 24\% / 12 = 2\% perbulan

- Total Pendapatan sebesar

94.785 .065 .976

- $2 \% \times 94.785 .065 .976$

$\underline{(1.895 .701 .319,52)}$

Pendapatan bersih yang di terima $92.889 .364 .656,5$ 
Jurnal Untuk mencatat pengakuan pendapatan saat input invoice di kantor pusat :

31 Jan 2014 Bank

94.785.065.976

$\begin{array}{ll}\text { Pendapatan Tol } & 92.889 .364 .656,5 \\ \text { Hutang Pajak } & 1.895 .701 .319,52\end{array}$

Page | - $116-$

Jurnal untuk mencatat pengakuan pendapatan di kantor cabang :

31 Jan 2014 Bank

94.785.065.976

Pendapatan Tol 94.785.065.976

\section{Pendapatan Bersifat Normal}

Perusahaan mengetahui seberapa besar penghasilan yang diperoleh dari pendapatan yang diterima melalui pendapatan utama tol dan pendapatan lainnya seperti penyewaan lahan untuk rest area dan sewa lahan untuk iklan, dimana setiap pendapatannya dapat diukur dengan dilihat dari jumlah kendaraan yang masuk ruas cawang sampai dengan ruas pluit, dan penyewaan lahan untuk rest area dan sewa lahan untuk iklan dengan asumsi harga tiket tol dan penyewaan lahan tersebut sudah ditentukan oleh perusahaan dan diakui setiap transaksinya.

\section{KESIMPULAN}

Penerapan pengakuan pendapatan yang digunakan oleh PT Jasa Marga (Persero) Tbk Cabang Cawang Cengkareng telah sesuai dengan PSAK No.23 Tahun 2010, dimana pendapatan perusahaan diakui pada saat direalisasi dan dihasilkan.

PT Jasa Marga melakukan kegiatan proses pencatatan pendapatan yang dimulai dari pendapatan tol ruas cawang sampai dengan pluit yang dikumpulkan pada bagian pengumpulan tol dan disetorkan ke bank. Di dalam melakukan kegiatan perusahaan, terdapat biaya biaya yang dibutuhkan untuk transaksi, maka PT Jasa Marga menerapkan Standar Operasional Perusahaan (SOP) untuk mengeluarkan biaya yang diperlukan selama kegiatan tersebut berlangsung.

PT Jasa Marga menerapkan Standar Pelayanan Minimum (SPM) untuk mendapatkan pendapatan yang bersifat normal dan kegiatan yang dilakukan oleh perusahaan dapat berjalan dengan baik. 


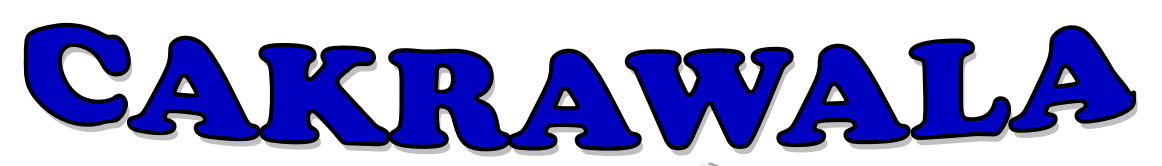

\section{Management Business Journal [C:M]-BJ] Volume 1 Nomor 1 Tahun 2018}

\section{REKOMENDASI}

Berdasarkan kesimpulan diatas maka peneliti akan memberikan saran sebagai bahan masukan dan pertimbangan bagi Perusahaan, yaitu Di dalam perlakuan akuntansi pendapatan khususnya mengenai pengakuan pendapatan PT Jasa Marga yang telah sesuai dengan PSAK No.23 harus dipertahankan dengan cara memperhatikan prosedur yang ada di dalam PSAK agar setiap periode akuntansi mengasilkan laporan keuangan yang lebih akurat.

Perusahaan harus lebih menerapkan Standar Operasional Perusahaan dengan cara memperhatikan biaya apa saja yang diperlukan selama kegiatan berlangsung, seperti biaya pemakaian kertas, biaya perawatan mesin, dan lain sebagainya agar kegiatan perusahaan dapat berjalan dengan baik dan lebih efisien.

Perusahaan harus lebih meningkatkan Standar Pelayanan Minimum terhadap kegiatan yang dilakukan dengan cara menerapkan standar kekesatan jalan, standar 6 detik, dan lain lain. Dengan menerapkan SPM ini diharapkan pendapatan dapat mengalami peningkatan yang lebih siginifikan.

\section{DAFTAR REFERENSI}

Bafadal, I. (2015). Pengelolaan Perpustakaan Sekolah. Jakarta: Bumi Aksara.

Belkoui, Ahmed Riahi. 2006. Teori Akuntansi Edisi Kelima. Jakarta: Salemba Empat.

Belkoui, Ahmed Riahi. 2013. Accounting TheoryBuku 1 Edisi 15. Jakarta:Salemba Empat

Desi Eliza Purba, 2018, Jurnal Ekonomi Bisnis , Universitas Maritim Raji Ali Haji, Volume 5, no.2, Januari 2018 Penerapan PSAK 23 Tentang Akuntansi Pendapatan Studi Pada PT Angkasa Pura II Bandar Udara Raja Haji Fisabilillah (RHF).

Harahap, Sofyan Syafri. 2011. Teori Akuntansi. Jakarta:Raja Grafindo.

Ikatan Akuntansi Indonesia. 2010. Standar Akuntansi Keuangan (PSAK) No.23

Ikatan Akuntansi Indonesia. 2012. Standar Akuntansi Keuangan. Jakarta: Salemba Empat.

Kusnadi. 2000. Akuntansi Keuangan Menengah (Intermidate). Malang: Universitas Brawijaya.

Miles,M.B, Huberman,A.M, dan Saldana,J. 2014. Qualitative Data Analysis, A Methods Sourcebook, Edition 3. USA: Sage Publications. Terjemahan Tjetjep Rohindi Rohidi, UI-Press. 


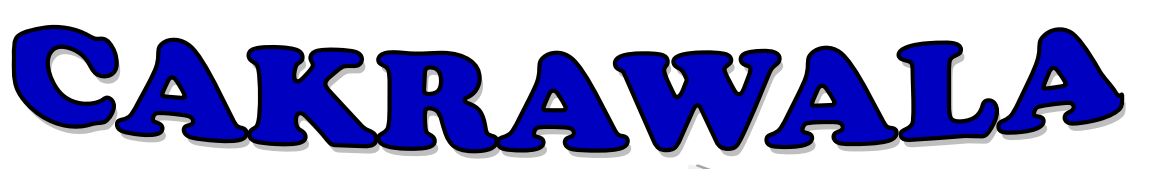

\section{Management Business Journal [CM:-BJ] Volume 1 Nomor 1 Tahun 2018}

Moleong, Lexy J. 2013. Metode Penelitian Kualitatif. Edisi Revisi. Bandung : PT. Remaja Rosdakarya

Patton, Michael Quinn. 2006 . Metode Evaluasi Kualitatif. Yogyakarta: Pustaka Pelajar.

R.K. Yin, Studi Kasus: Desain dan Metode ,Edisi Bahasa Indonesia, (Jakarta: Raja Grafindo, 2002), hlm. 25

Rina Dwirinawati, 2017. Jurnal Ilmu dan Riset Akuntansi, Volume 6, no.1, Januari 2017, Sekolah Tinggi ilmu Ekonomi Indonesia, Surabaya, Pengakuan dan Pengukuran Pendapatan Menurut PSAK Pada Perusahaan Biro Jasa Perjalanan.

Samryn, L.M. 2014. Pengantar Akuntansi Cetakan Ketiga. Jakarta: Rajawali Pers.

Santoso, Imam. 2010. Akuntansi Keuangan Menengah (Intermidate Accounting). Bandung:Buku Satu Refika Aditama

Suwardjono. 2008. Teori Akuntansi Perekayasa Pelaporan Keuangan. Yogyakarta: BPFE. 